\title{
Reformulation of Article 185 Paragraph 1 Indonesia Criminal Procedure Code Related to Legal Certainty of the Use De Auditu Witnesses as a Legislative Evidence
}

\author{
Yanels Garsione Damanik* ${ }^{*}$ Aditya Wardana Sofarisman Jayadi M. Wakin Bugi Heru Priantama \\ Master of Law, Postgraduate Faculty of Law, Brawijaya University, 169 MT. Haryono Street, 65145 Malang \\ City, East Java, Indonesia
}

\begin{abstract}
The juridical implication of the emergence of the Constitutional Court Decision Number 65/PUU-VIII/2010 is expanding the meaning of witness. However, related to this, some things appear to be big problems related to legal certainty in the use of de auditu witnesses. Meanwhile, in the Criminal Procedure Code, the use of de auditu witnesses is very much against Article 185 paragraph 1 and its explanations. This research is normative legal research with approaches through the statue, cases, conceptual, comparative approaches and by using analytical techniques, namely teleological interpretation, and extensive interpretation and in this normative legal research approach using legal certainty theory, legal hierarchy theory, and relevance theory in evidence whose purpose is to find answers regarding that, in fact, testimonium de auditu can be used in criminal justice in Indonesia with the conditions specified in the decision of the constitutional court and the conditions specified in the Criminal Procedure Code, but before that Article 185 paragraph, 1 and its explanations must be reformulated to create certainty law.
\end{abstract}

Keywords: Reformulation, Legal Certainty, Testimonium De Auditu

DOI: $10.7176 / \mathrm{JLPG} / 112-20$

Publication date:August $31^{\text {st }} 2021$

\section{Introduction}

Evidence is seen from the perspective of criminal procedural law, which is evidence-based on provisions that limit court proceedings in an effort to find and defend the truth, both by judges, public prosecutors, defendants and legal advisers, all of which are bound by the provisions and procedures, as well as the assessment of evidence. determined by law. It is not justified to take independent actions in assessing evidence and must not conflict with the law (Hiariej, 2013, p. 7).

After the issuance of the Constitutional Court Decision Number 65/PUU-VIII/2010, there was a change in the meaning of witnesses and witness statements contained in Article 1 number 26 and Article 1 number 27 in Law Number 8 of 1981 concerning criminal procedural law that what is included in the testimony of witnesses is also the information obtained without having to see for yourself, hear for yourself, and experience it for yourself and must be in accordance with the events of the crime In criminal procedural law this is known as a

\section{TESTIMONIUM DE AUDITU.}

This raises a fairly large problem that is conflicting legal norms in article 185 paragraph 1 of the Criminal Procedure Code and the Constitutional Court Decision, and this is also related to legal certainty, because in law number 8 of 1981 concerning criminal procedural law, Article 185 paragraph 1 and its explanation provide an explanation that witness statements that can be used as evidence are statements of witnesses who given before a court where the information is not sourced from another person. The definition of a witness de auditu is a witness who hears from other people (Article 185 paragraph 1 and its explanation).

In his book entitled "Theory and Law of Evidence", Eddy Omar Sharif Hiariej argues that : "Tesimonium de auditu can be defined as statements about the facts and things that are heard, seen, or experienced not by the witness himself, but by the testimony given by him. conveyed by others to him about the facts and things that are heard, seen, and experienced by the other person."(Hiariej, 2013, p. 60).

In his book entitled "Indonesian Criminal Procedure Law", Andi Hamzah explains: "Testimonium de auditu is witness testimony obtained from stories or words of other people."(Andi, 2008, p. 264). Then furthermore, Jonaedi Efendi argues that the : "Testimonium de auditu is the testimony of a witness presented before a court hearing which is the result of thought alone or the result of a fabrication obtained from other people."(Efendi, 2009, p. 112). Based on these opinions, it can be concluded that testimonium de auditu is the testimony of witnesses whose sources are obtained from stories or words expressed by other people.

For the type of evidence, The Criminal Procedure Code has stipulated in Article 185 paragraph 1 of the Criminal Procedure Code, and its explanation very firmly rejects the de auditu statement in proving a crime, but over time there has been a change in the acceptance of evidence in Indonesia. Evidence in the Criminal Procedure Code is limited it is contained in article 184 of the Criminal Procedure Code of which are: 
1. Witness testimony,

2. Expert testimony,

3. Letters,

4. Indications, and

5. Testimony of the defendant (Monang Siahaan, 2017, p. 104) and testimonium de auditu is not a piece of evidence that is considered to exist.

However, as a result, the decision of the Constitutional Court was issued, the testimonium de auditu has a position in legal evidence to prove a crime on the condition that it has relevance to the crime (Subiyanto and Agustine, 2019, p. 16). After that, there were pro and contra opinions regarding the acceptance of de auditu witnesses as evidence. those who are pro give opinions:

1. In this way, not a single piece of evidence is lost, otherwise even if it exists, it will not be reported before the judge,

2. Witness statements are untrue and unrelated if de auditu's statements are intentionally omitted,

3. Testimonium de auditu was not mentioned before the judge, it is undeniable that it helped strengthen the judge's belief, it is better if the judge in his consideration mentions the evidence to what extent de auditu's statement has a role in the preparation of evidence,

4. It is illogical if a statement is often issued based on emotional state and being heard for justice are accepted as evidence, and similarly does not receive a notification which according to witness testimony was explained to him by another person in calm and serenity circumstances (Andi, 2008, p. 268).

Then the party who contradicts provides the following argument:

1. If so, it is possible to prove from the second or third hand,

2. If the witness's testimony only has value if it is given an oath, it is also evidence,

3. Clearly, the entire implementation of the evidence may be concentrated on the police or investigators whose minutes of creating the law as well as the principle of direct examination by a judge have been cut off (Andi, 2008, p. 268).

Substantially, testimonum de auditu may not be used in proving a criminal act. The testimonum de auditu in the law, especially the Criminal Procedure Code, is not recognized for its existence and its position as evidence. But in practice it was found that testimony was considered as evidence in certain cases, for example:

1. The case of premeditated murder involving a minor committed by Yusman Telaumbanua, Rusula Hia, and friends in 2013 (Gunung Sitoli District Court Decision Number 8/Pid/B/2013/PN-GST which overturned by Supreme Court Decision Number 96 PK/Pid/2016 On January 31, 2017, with the decision to retrial Yusman Telaumbanua, which was originally a death penalty by a district court judge, turned into participating in a criminal act),

2. The cyanide coffee case carried out by the suspect Jessica Kumala Wongso with the victim named Mirna Salihin (Central Jakarta District Court Decision Number 777/Pid.B/2016/PN.JKT.PST dated 27 October 2016),

3. The blasphemy case by Ir. Basuki Tjahaja Purnama or better known as Ahok, in North Jakarta District Court Decision Number 1537/Pid.B/2016/PN JKT.UTR Dated May 9, 2017,

This raises an uncertainty and the Criminal Procedure Code should strictly regulate the use of de auditu witnesses in criminal evidence.

\section{Research Method}

The type of research used is normative research which focuses on identifying, describing reformulation of article 185 paragraph 1 Indonesia criminal procedure code related to legal certainty of the use de auditu witnesses as a legitive evidence. In conducting normative research, several approach methods can be used, namely: statue approach, case approach, conceptual approach and comparative approach. The techniques used in this research are extensive interpretation techniques and teleological interpretations. What is meant by extensive interpretation here is Extensive Interpretation, which is an interpretation method that interprets the usual limits carried out through interpreting.(Rifai, 2010, p. 71)

Extensive interpretation is used to explain a statutory provision beyond the limits given by grammatical interpretation. the author's evidence in interpreting a legal rule in Article 1 paragraph 26, Article 1 paragraph 27 of the Criminal Code and Article 185 paragraph of the Criminal Procedure Code. In addition to using an extensive interpretation, this research uses a teleological interpretation related to the meaning of laws determined based on social goals. With this teleological interpretation, the law is still valid but is no longer applied to current events, relationships, and interests, no matter whether this is every time legislation is promulgated that is adapted to new social relationships and situations.(Purwati, 2020, p. 56) In this case, the use of witness testimony de audit, which has been prohibited from being used in Article 185 paragraph 1 and the Elucidation of the Criminal Procedure Code can be used on the condition that the testimony of the witness de auditu is in accordance with 
the event of a crime (Constitutional Court Decision Number 65/PUU-VIII/2010 and this can be included as evidence especially as indication evidence (Article 188 paragraph 1 of the Criminal Procedure Code) the next is that the testimony of the de auditu witness is not based on his own thoughts or fiction (Article 185 paragraph 5 of the Criminal Procedure Code), but has a conformity or relationship with the testimony of other witnesses.

\section{Result and Discussion}

A. LEGAL CERTAINTY REGARDING THE RECEIPT OF TESTIMONIUM DE AUDITU AS EVIDENCE BY REFORMULATING OF ARTICLE 185 PARAGRAPH 1 AND ITS EXPLANATION

The expansion of the meaning of witness and witness testimony includes article 1 number 26 and article 1 number 27 of the Criminal Procedure Code, after the enactment of the Constitutional Court Decision Number 65/PUU-VIII/2010 this broadly affects the Criminal Procedure Code, that is The statements of witnesses that can be used as evidence in the Criminal Procedure Code also include information of witnesses who did not see directly, did not experience directly and did not hear directly of a criminal act, but whose statements have relevance to the events of the crime, this is particularly contradictory with Article 185 paragraph 1 of the Criminal Procedure Code and its explanation which states that witness statements can be used as evidence if they meet the following requirements:

1. Information presented at the front court

2. The source is not from someone else or Testimonium De Auditu.

As a result of the conflicting norms between the constitutional court decisions and the Criminal Procedure Code, it creates a legal uncertainty regarding the acceptance of de auditu as evidence in criminal procedural law. Normative legal certainty is when a regulation is made and promulgated with certainty because it regulates clearly and logically. It is clear in the sense that it does not cause doubt (multi-interpretation) and is logical. It becomes a norm system with other norms so that it does not clash or cause norm conflicts. Legal certainty refers to the application of a clear, permanent, consistent and consequent law whose implementation cannot be influenced by subjective circumstances. Certainty and justice are not just moral demands, but factually characterize the law. An uncertain and unjust law is not just a bad law (Tarigan, 2017, p. 16).

According to Van Apeldoorn, "legal certainty" can also mean things that can be determined by law in concrete matters". The legal certainty of the guarantee is that the law is carried out, that those who are entitled to obey the law can obtain its rights and that decision can be enforced. Legal certainty constitutes justiciable (justice seeker) protection against arbitrary action which means that someone will get something expected under certain circumstances.(Prayogo, 2018, p. 194).

The principle of legal certainty, in fact, the existence of the principle is interpreted as a situation where the law is certain because of the power concrete for the law in question. The existence of the principle of legal certainty is a form of protection for justiciable (justice seeker) against arbitrary actions authority, which means that someone will and can get something that is expected under certain circumstances(Julyano and Sulistyawan, 2019, p. 14). Lord Lloyd is of the opinion that :

"...law seems to require a certain minimum degree of regularity and certainty ,for without that it would be impossible to assert that what was operating in a given territory amounted to a legal system"

From this view, it can be understood that without legal certainty, people don't know what to do, and finally, uncertainty arises (uncertainty) which will eventually lead to violence (chaos) due to indecision legal system. Thus, legal certainty points to the implementation of clear, permanent and consistent law whose implementation cannot be influenced by subjective circumstances (Julyano and Sulistyawan, 2019).

When it is associated with the use of testimonials de auditu, there is a dualism of thought between those who accept and reject the testimony based on conflicting norms between the Criminal Procedure Code and the Constitutional Court Decision Number 65/PUU-VIII/2010.

But the constitutional court believes that :

"The context of evidence in criminal law is not only to prove whether the suspect or defendant has committed or is involved in certain criminal acts/actions, but also includes proving that an act/criminal act has actually occurred and is not limited only to the meaning contained in Article 1 points 26 and 27."(Butarbutar, 2016, p. 140)

Then the constitutional court requires that in using witness statements whose sources are obtained from other people, their statements must have relevance to the event of a criminal act and not merely the result of thought. According to the Indonesian Dictionary, relevance means relationship, connection.(Arto, 2011, p. 140) Meanwhile, according to Sukmadinata, relevance consists of internal relevance and external relevance. Internal relevance is the suitability or consistency between components such as objectives, content, delivery, and evaluation processes, or in other words, internal relevance concerns the integration between components. While external relevance is in accordance with the needs, needs, and developments in society (Dayantri, 2019, p. 9).

According to the opinion of Munir Fuady, a relevant tool of evidence is a tool of proof where the use of the 
evidence in the trial process is more likely to make it a fact. Relevance of evidence is measured by whether or not a criminal act is proven or not and seeks its connection with the criminal event.(Fuady, 2020, p. 4). If the evidence is irrelevant, the court must reject the evidence because accepting irrelevant evidence will carry certain risks to the justice-seeking process, including :

1. A waste of time so that it can slow down the judicial process.

2. Can be misleading which gives rise to unnecessary assumptions.

3. Assessment of the problem becomes disproportionate by exaggerating what is actually small, or minimizing what is actually big.

4. Making the judicial process irrational.

Related to legal certainty regarding the testimonium de auditu as evidence, the first basis that needs to be understood is the philosophical purpose of the creation of the Criminal Procedure Code. Philosophical basis, the changes in the rules of criminal procedure law from the Het Herziene Inlandsch Reglement (HIR) to the Criminal Procedure Code are also inseparable from differences in values that grow and develop in society, especially the values of respect for human rights which have been echoed internationally since the Declaration of Human Rights by the United Nations on 12 December 1948 (Wisnubroto and Widiartana, 2005, p. 11). Then the Indonesian government adopted several articles in the General Declaration of Human Rights from the United Nations and adapted them to the Indonesian nation's culture, religion, and character in the Second Amendment to the 1945 Constitution. Then regarding the protection of human rights in the 1945 constitution, it is also adopted in the Criminal Procedure Code, with One of the rights protected by the The 1945 Constitution of the Republic of Indonesia is Article 28 D Paragraph 1 which reads, "Every person shall have the right of recognition, guarantees, protection and certainty before a just law, and of equal treatment before the law." Article $28 \mathrm{D}$ paragraph 1 of the Constitution of the Republic of Indonesia is the basis for guaranteeing legal certainty regarding testimony de auditu as evidence and if it is related to Hans Kelsen's theory of level norms, it is said that legal norms are tiered and layered in a hierarchy of structure, where a lower standard applies, originates, and is based on a higher bar (Marjan Miharja, 2019, p. 35). Then the source of the KUHAP is the 1945 Constitution of the Republic of Indonesia by the hierarchy of legislation in Article 7 of Law Number 12 of 2011 in conjunction with Law Number 15 of 2019 concerning the Establishment of Legislation.

The juridical basis to ensure legal certainty relating to the use of testimonium de auditu as evidence, it is necessary to reformulating the Criminal Procedure Code, especially Article 185 paragraph 1 and its explanation with the standard legality principle (Article 3) in the Criminal Procedure Code. The principle of legality or nullum iudicium sine lege, summarized in (Article 3) of the Criminal Procedure Code states that the enforcement of criminal law (including the judiciary) is carried out according to the method stipulated in the legislation.(Moeliono, 2015, p. 599). Formal principles contained in the principle of legality, namely(Kasim and Nusa, 2019, p. 13):

1. Scripta principle

The rules that include and write down the criminal procedure law must be clear, this is intended to guarantee legal certainty.

2. Certa principle According to this principle, the criminal procedural law that regulates the proceedings with all existing authorities must be in writing.

3. Stricta principle

According to this principle, the rules in criminal procedural law must interpreted strictly, meaning that the consequence of this rule is that the provisions in criminal procedural law cannot be interpreted other than what is written.

Then, combined with the principle of lex posterior derogat legi priori, the new law (norm/rule of law) nullifies the validity of the old law (norm/rule of law). This principle can only be applied in conditions where the new legal norms have an equal or higher position than the old legal norms. This is related to the previous explanation, that the relationship between norms is a relationship between "superordination" and "subordination" where the validity of lower norms always comes from higher norms (Irfani, 2020, p. 312).

The norm states that with the enactment of the new regulations, the old regulations are declared revoked and invalid. This has been in drafting laws and regulations as regulated in Attachment II of Law no. 12 of 2011 (Irfani, 2020). Several technical provisions for the preparation of laws and regulations relating to the application of this principle include the following (Irfani, 2020):

1. If the content of the new Laws and Regulations causes a change or replacement of all or part the range of the old Laws and Regulations, the new Laws and Regulations must expressly stipulate the revocation of all or part of the contents of the Laws and Regulations - old invitation. In this case, the decision of the Constitutional Court causes a change in the meaning of witnesses and witness testimony, which originally had to see, hear and experience, must also be eaten by witnesses and witness statements are those who do not see, hear and experience themselves but have relevance to the 
crime incident.

2. For the sake of legal certainty, changes to the norms in article 185 paragraph 1 and its explanation.

Then based on the principle of legality in the KUHAP and based on the Lex Posteriori derogat lex priori, a conclusion was reached to ensure legal certainty as a human right that is protected in the Indonesian constitution and in the KUHAP, Article 185 paragraph 1 of the Criminal Procedure Code and its explanation need to be reformulated again into :

"The testimony of the witness as evidence is what the witness stated in court, including the testimony of the de auditu witness." In the case of receiving a testimonial de auditu, it must meet the following requirements:

1. Can reveal the process of the occurrence of criminal acts,

2. Conformity with witness statements and other evidence,

3. Proposed because the person who should be a witness is sick and cannot be presented at trial,

4. The testimony of the witness de auditu must be sworn in,

5. The testimony of de auditu witnesses in legal evidence, the more appropriate position is as evidence of guidance because its nature in proving is not direct but through actions, events or circumstances which due to their correspondence with one another or with the crime itself indicates that a crime has occurred and who the perpetrator is.

\section{B. THE POSITION OF THE TESTIMONIUM DE AUDITU AS EVIDENCE AND THE CONDITIONS} THAT MUST BE MET AS EVIDENCE.

The juridical implications arising from the issuance of the Constitutional Court's decision Number 65/PUUVIII/2010 are regarding the position of the testimony de auditu in Indonesian criminal procedure law. The juridical implications arising from the issuance of the Constitutional Court's decision Number 65/PUU-VIII/2010 are regarding the position of the testimony de auditu in Indonesian criminal procedure code. This development can seen from several cases that use testimonium de auditu as indication of evidence in proving a criminal act, namely:

Table 1. The basis of judges' considerations in the Indonesian Criminal Court relates to testimony de auditu as evidence.

\begin{tabular}{|c|c|c|c|}
\hline No & Case & Legal Argument & Conclusion \\
\hline 1 & $\begin{array}{l}\text { The case of premeditated murder } \\
\text { involving a minor committed by } \\
\text { Yusman Telaumbanua, Rusula } \\
\text { Hia, and friends in } 2013 \text { (Gunung } \\
\text { Sitoli District Court Decision } \\
\text { Number } 8 / \mathrm{Pid} / \mathrm{B} / 2013 / \mathrm{PN}-\mathrm{GST} \\
\text { which overturned by Supreme } \\
\text { Court Decision Number } 96 \\
\text { PK/Pid/2016 On January } 31,2017 \text {, } \\
\text { with the decision to retrial Yusman } \\
\text { Telaumbanua, which was } \\
\text { originally a death penalty by a } \\
\text { district court judge, turned into } \\
\text { participating in a criminal act }\end{array}$ & $\begin{array}{l}\text { Whereas based on the testimony of the } \\
\text { de auditu witness, the judge saw that it } \\
\text { was in accordance with the statements } \\
\text { of the other defendants (Article } 184 \\
\text { letter e of the Criminal Procedure } \\
\text { Code in conjunction with Article } 185 \\
\text { paragraph } 4 \text { of the Criminal Procedure } \\
\text { Code in conjunction with Article } 185 \\
\text { paragraph } 6 \text { ), namely Rusula Hia who } \\
\text { stated that the role of the Defendant } \\
\text { YUSMAN only played a role in } \\
\text { throwing the corpse into the ground } \\
\text { ravine, because JENI ordered. }\end{array}$ & $\begin{array}{l}\text { The role of the testimony } \\
\text { de auditu is as a means } \\
\text { of indicative evidence } \\
\text { through proof that is } \\
\text { carried out by means of } \\
\text { chain evidence (Article } \\
185 \text { paragraph } 4 \text { in } \\
\text { conjunction with Article } \\
185 \text { paragraph } 6 \text { of the } \\
\text { Criminal Procedure } \\
\text { Code) }\end{array}$ \\
\hline
\end{tabular}




\begin{tabular}{|c|c|c|c|}
\hline No & Case & Legal Argument & Conclusion \\
\hline 2 & $\begin{array}{l}\text { The cyanide coffee case carried out } \\
\text { by the suspect Jessica Kumala } \\
\text { Wongso with the victim named } \\
\text { Mirna Salihin (Central Jakarta } \\
\text { District Court Decision Number } \\
\text { 777/Pid.B/2016/PN.JKT.PST } \\
\text { dated } 27 \text { October 2016), }\end{array}$ & $\begin{array}{l}\text { None of the eyewitnesses at Olivier } \\
\text { saw the convict Jessica Kumolo } \\
\text { Wongso put cyanide (poison) in } \\
\text { Mirna's coffee. However, of the } 15 \\
\text { witnesses at Cafe Olivier, all agreed } \\
\text { that only Jessica had control and was } \\
\text { at table } 54 \text { (the crime scene). At this } \\
\text { stage the judge made a sharp } \\
\text { observation of the incident. As an } \\
\text { example : } \\
\text { 1. Exploring the instructions (Article } \\
\text { 184 letter d of the Criminal Procedure } \\
\text { Code in conjunction with Article } 185 \\
\text { paragraph } 4 \text { in conjunction with } \\
\text { Article } 185 \text { paragraph } 6 \text { of the } \\
\text { Criminal Procedure Code) obtained } \\
\text { through CCTV when Jessica's hand } \\
\text { was pulling something from the coffee } \\
\text { cup before the victim Mirna came with } \\
\text { her friend, Hani, and sat at table } \\
\text { number } 54 \text {. } \\
\text { 2. The witness from Olivier's Cafe also } \\
\text { saw that the color of the coffee had } \\
\text { turned brass. Moments later, witness } \\
\text { Olivier turned his head as Mirna } \\
\text { fainted, Mirna's lips turned blue/black, } \\
\text { and within seconds died. And based on } \\
\text { correspondence with other evidence } \\
\text { and witnesses, the judge concluded } \\
\text { that Jessica Kumala wongso was found } \\
\text { guilty of premeditated murder. }\end{array}$ & $\begin{array}{l}\text { The role of the testimony } \\
\text { de auditu is as a means } \\
\text { of indicative evidence } \\
\text { through proof that is } \\
\text { carried out by means of } \\
\text { chain evidence (Article } \\
185 \text { paragraph } 4 \text { in } \\
\text { conjunction with Article } \\
185 \text { paragraph } 6 \text { of the } \\
\text { Criminal Procedure } \\
\text { Code) }\end{array}$ \\
\hline 3 & $\begin{array}{l}\text { The blasphemy case by Ir. Basuki } \\
\text { Tjahaja Purnama or better known } \\
\text { as Ahok, in North Jakarta District } \\
\text { Court Decision Number } \\
\text { 1537/Pid.B/2016/PN JKT.UTR } \\
\text { Dated May 9, 2017. }\end{array}$ & $\begin{array}{l}\text { In this case, the court believes that } \\
\text { although the testimony of the reporting } \\
\text { witness is a testimony de auditu, the } \\
\text { testimony by the witness is in } \\
\text { accordance with the Constitutional } \\
\text { Court Decision Number 65/PUU- } \\
\text { VIII/2010 dated } 8 \text { August } 2011 \text { which } \\
\text { states that the importance of the } \\
\text { witness does not lie in whether he sees, } \\
\text { heard, or experienced a criminal act } \\
\text { personally, but LOCATED ON THE } \\
\text { RELEVANCE OF HIS } \\
\text { TESTIMONY C WITH THE } \\
\text { CRIMINAL CASE PROCESSED. }\end{array}$ & $\begin{array}{l}\text { The role of the testimony } \\
\text { de auditu is as a means } \\
\text { of indicative evidence } \\
\text { through proof that is } \\
\text { carried out by means of } \\
\text { chain evidence (Article } \\
185 \text { paragraph } 4 \text { in } \\
\text { conjunction with Article } \\
185 \text { paragraph } 6 \text { of the } \\
\text { Criminal Procedure } \\
\text { Code) }\end{array}$ \\
\hline \multicolumn{2}{|c|}{ Results } & \multicolumn{2}{|c|}{$\begin{array}{l}\text { Based on these decisions, it can be concluded that the basis for } \\
\text { using witness testimony de auditu is Constitutional Court Decision } \\
\text { Number 65/PUU-VIII/2010. The condition is that HIS } \\
\text { TESTIMONY is RELEVANT WITH PROCESSED CRIMINAL } \\
\text { CASES. The method of proof using testimonials de auditu is chain } \\
\text { evidence (Ketting Bewijs) of Article } 185 \text { paragraph } 4 \text { of the } \\
\text { Criminal Procedure Code and see the conformity (Article } 185 \\
\text { paragraph } 6 \text { of the Criminal Procedure Code) and from the } \\
\text { statements of testimonials de auditu that are mutually compatible } \\
\text { form a guide. So the position of testimony de auditu in Article } 184 \\
\text { paragraph } 1 \text { of the Criminal Procedure Code is as indication } \\
\text { evidence. }\end{array}$} \\
\hline
\end{tabular}

This makes it possible to receive witnesses who have not seen, heard, and experienced themselves. Still, 
based on notifications from other people (testimonium de auditu) on the condition that the information submitted must have a criminal act as long as testimonials de auditu can meet these conditions, then testimonium de auditu should accept it. The testimony of the de auditu witness as evidence that is prioritized is the suitability of which is also to confirm the truth of the previous testimonies and this makes the de auditu testimony have a position in criminal procedural law as evidence.

The following is a comparison which is the reason that testimonium de auditu are more suitable as evidence of guidance compared to being used as evidence of witness testimony:

Table 2 Comparison of Witness Statements and Indication Evidence

\begin{tabular}{|c|c|c|c|}
\hline No & Indicator & Witness testimony & Indication Evidence \\
\hline 1 & Legal basis & $\begin{array}{l}\text { Article } 1 \text { number } 27 \text { of the } \\
\text { Criminal Procedure Code in } \\
\text { conjunction with Article } 184 \\
\text { letter a of the Criminal } \\
\text { Procedure Code }\end{array}$ & $\begin{array}{l}\text { Article } 184 \text { letter } \mathrm{d} \text { of the Criminal Procedure } \\
\text { Code in conjunction with Article } 188 \text { paragraph } \\
1 \text { of the Criminal Procedure Code }\end{array}$ \\
\hline 2 & Definition & $\begin{array}{l}\text { Witness testimony is one of the } \\
\text { pieces of evidence in a criminal } \\
\text { case in the form of testimony } \\
\text { from a witness regarding a } \\
\text { criminal event that he heard, } \\
\text { saw, and experienced by } \\
\text { mentioning the reasons for his } \\
\text { knowledge. }\end{array}$ & $\begin{array}{l}\text { Indication are actions, events, or circumstances, } \\
\text { which because of compatibility, both between } \\
\text { one and another, as well as } \\
\text { with the crime itself, indicating that a crime has } \\
\text { occurred and who the perpetrator is. }\end{array}$ \\
\hline 3 & $\begin{array}{l}\text { The nature of the } \\
\text { proof }\end{array}$ & Direct Evidence & Circumtantial Evidence \\
\hline 4 & How to Prove & Unus Testis Nullus Testis: & Ketting Bewijs \\
\hline 5 & The Power of Proof & $\begin{array}{l}\text { Witness testimony has strong } \\
\text { evidentiary power because it } \\
\text { can be concrete about the } \\
\text { occurrence of an act of fact that } \\
\text { occurred. } \\
\text { To avoid the occurrence of } \\
\text { Unus Testis Nullus Testis, } \\
\text { witness statements are } \\
\text { combined with expert witnesses } \\
\text { and the defendant's statements } \\
\text { to form a legal fact. }\end{array}$ & $\begin{array}{l}\text { In the event that a legal fact forms because the } \\
\text { nature of the evidence is indirect, it requires } \\
\text { confirmation from other witnesses and other } \\
\text { evidence so that a legal fact emerges and } \\
\text { determines who the real perpetrator is. } \\
\text { Regarding the accuracy of the witnesses, the } \\
\text { clues depend on the accuracy of the witnesses } \\
\text { who can support their statements, unlike the } \\
\text { fact witnesses who can specifically explain the } \\
\text { perpetrators and the events of the crime. }\end{array}$ \\
\hline \multicolumn{3}{|c|}{ Conclusion } & $\begin{array}{l}\text { Testimonium de auditu is witness testimony } \\
\text { that relies on conformity with other witnesses } \\
\text { and other evidence; this chain of evidence } \\
\text { shows that only legal facts can be established } \\
\text { regarding the incident of a criminal act and who } \\
\text { the perpetrators are or who are involved in the } \\
\text { criminal act. Then this matter is explored again } \\
\text { until it finds the real culprit. It is different from } \\
\text { a fact witness who is able to provide clear } \\
\text { specifications about the occurrence of a } \\
\text { criminal act and who the real perpetrator is. }\end{array}$ \\
\hline
\end{tabular}

Article 188 paragraph 1 requires that an important clue is to show that the criminal incident actually occurred and who the real perpetrator was. This is when it is associated with the testimonium de auditu after the enactment of the Constitutional Court Decision Number 65/PUU-VIII/2010, the de auditu witness has the position as evidence of evidence with the strength of his proof being relevant to the crime incident, namely

1. Relevance to other witnesses, and

2. Relevance with other evidence.

With the assessment indicators, it is entirely up to the judge to make a decision careful and wisely. The goal is that none of the events in the criminal act are missed and that in the future, testimonium de auditu as indication evidence will really give a fair decision. 


\section{Conclusion}

The urgency of the reformulation of article 185, paragraph 1 of the Criminal Procedure Code and its explanations to ensure that human rights are upheld, especially regarding legal certainty for everyone. If Article 185 paragraph 1 and its explanation are not reformulated, there will be dualism in the law and this will lead to conflicts between norms because in reality the rule of law must be firm so as not to mislead. The next stage is that after Article 185, paragraph 1 of the Criminal Procedure Code and its explanation is reformulated, the testimony de auditu can be used as evidence. Its position is a piece of indicative evidence.

\section{References}

\section{Book and Journal}

Andi, H. (2008) 'Hukum Acara Pidana Indonesia', Jakarta: Sinar Grafika.

Arto, M. (2011) 'Praktek Perkara Perdata pada Pengadilan Agama, cet. ke-9', Yogyakarta: Pustaka Pelajar.

Butarbutar, E. N. (2016) Hukum pembuktian: analisis terhadap kemandirian hakim sebagai penegak hukum dalam proses pembuktian. Nuansa Aulia.

Dayantri, H. (2019) 'Relevansi Kurikulum Program Studi Ilmu Perpustakaan Fakultas Adab Dan Humaniora Uin Raden Fatah Palembang Dengan Standar Kompetensi Kerja Nasional Indonesia (Skkni)(Studi Analisis Dunia Kerja Alumni)'. Program Studi Ilmu Perpustakaan.

Efendi, J. (2009) Kamus Istilah Hukum Populer. Prenadamedia Group. Available at: https://books.google.co.id/books?id=4KRPDwAAQBAJ.

Fuady, M. (2020) Teori Hukum Pembuktian Pidana dan Perdata, Cetakan ke-3, Bandung: PT. Citra Aditya Bakti.

Hiariej, E. O. S. (2013) 'Teori dan Hukum Pembuktian'.

Irfani, N. (2020) 'ASAS LEX SUPERIOR, LEX SPECIALIS, DAN LEX PESTERIOR: PEMAKNAAN, PROBLEMATIKA, DAN PENGGUNAANNYA DALAM PENALARAN DAN ARGUMENTASI HUKUM', Jurnal Legislasi Indonesia, 17(3), pp. 305-325.

Julyano, M. and Sulistyawan, A. Y. (2019) 'Pemahaman terhadap asas kepastian hukum melalui konstruksi penalaran positivisme hukum', Crepido, 1(1), pp. 13-22.

Kasim, R. and Nusa, A. (2019) 'Hukum Acara Pidana: Teori, Asas, Dan Perkembangannya Pasca Putusan Mahkamah Konstitusi’, Malang: SetaraPress.

Marjan Miharja, S. H. M. H. (2019) Gesetzgebungswissenschaft: Bahan Ajar Ilmu Perundang-undangan. CV. Penerbit Qiara Media.

Moeliono, T. P. (2015) 'Asas Legalitas dalam Hukum Acara Pidana: Kritikan terhadap Putusan MK tentang Praperadilan', Jurnal Hukum Ius Quia Iustum, 22(4), pp. 594-616.

Monang Siahaan, S. H. (2017) Falsafah dan Filosofi Hukum Acara Pidana. Gramedia Widiasarana Indonesia.

Prayogo, T. (2018) 'Penerapan Asas Kepastian Hukum Dalam Peraturan Mahkamah Agung Nomor 1 Tahun 2011 Tentang Hak Uji Materiil Dan Dalam Peraturan Mahkamah Konstitusi Nomor 06/Pmk/2005 Tentang Pedoman Beracara Dalam Pengujian Undang-Undang', Jurnal Legislasi Indonesia, 13(2), pp. 191-201.

Purwati, A. (2020) 'Metode penelitian hukum teori \& praktek'. Jakad Media Publishing.

Rifai, A. (2010) Penemuan hukum oleh hakim: dalam perspektif hukum progresif. Sinar Grafika. Available at: https://books.google.co.id/books?id=QwXVYgEACAAJ.

Subiyanto, A. E. and Agustine, O. V. (2019) Yurisprudensi hukum acara pidana dalam putusan Mahkamah Konstitusi. Rajawali Pers.

Tarigan, L. (2017) 'Tinjauan Hukum Terhadap Perjanjian Sewa Menyewa Antara PT. Tuntungan Indahlestari Raya dengan Kodam I/BB Dalam Hal Pengelolaan Lapangan Golf (Studi Kasus Lapangan Golf Bukit Barisan Country Club (BBCC) Tuntungan Medan)'. Universitas Medan Area.

Wisnubroto, A. and Widiartana, G. (2005) 'Pembaharuan Hukum Acara Pidana. Cet. 1'. 